\title{
Effect of Adding Sb on Microstructure, Mechanical Properties and in Vitro Degradation Behavior of as Cast Mg-4wt\% Zn Alloy for Medical Application
}

\author{
Hadeer I. Mohamed1,2*, Mohamed E. Moussa ${ }^{3}$, Mohamed A. Waly ${ }^{3}$, Gamilla S. Al-Ganainy4, \\ Aya B. Ahmed ${ }^{1}$, Mona S. Talaat ${ }^{1}$ \\ ${ }^{1}$ Biophysics Group, Physics Department, Faculty of Science, Ain Shams University, Cairo, Egypt \\ ${ }^{2}$ Department of Neuroscience Technology, College of Applied Medical Sciences in Jubail, Imam Abdulrahman Bin Faisal \\ University, Jubail, Kingdom of Saudi Arabia \\ ${ }^{3}$ Department of Manufacturing Technology, Laboratory of Foundry, Central Metallurgical Research and Development Institute \\ (CMRDI), Helwan, Egypt \\ ${ }^{4}$ Physics Department, Faculty of Science, Ain Shams University, Cairo, Egypt \\ Email: *hiibrahim@uod.edu.sa
}

How to cite this paper: Mohamed, H.I., Moussa, M.E., Waly, M.A., Al-Ganainy, G.S., Ahmed, A.B. and Talaat, M.S. (2017) Effect of Adding $\mathrm{Sb}$ on Microstructure, Mechanical Properties and in Vitro Degradation Behavior of as Cast $\mathrm{Mg}-4 \mathrm{wt} \% \mathrm{Zn}$ Alloy for Medical Application. Journal of Surface Engineered Materials and Advanced Technology, 7, 69-85. https://doi.org/10.4236/jsemat.2017.74007

Received: September 22, 2017

Accepted: October 23, 2017

Published: October 26, 2017

Copyright $\odot 2017$ by authors and Scientific Research Publishing Inc. This work is licensed under the Creative Commons Attribution International License (CC BY 4.0).

http://creativecommons.org/licenses/by/4.0/

c) (i) Open Access

\begin{abstract}
Magnesium ( $\mathrm{Mg}$ ) and its alloys are one of a novel kind of biodegradable metallic implants which attracted much fundamental research to develop its clinical application. Nevertheless, it has more restrictions in biomedical applications because it degrades too fast at the early stage after implantation, thus commonly leading to some problems such as early fast mechanical loss, hydric bubble aggregation, gap formation between the implants and the tissue. This work aims to study the effect of $0.5 \mathrm{wt} \% \mathrm{Sb}$ addition on the microstructure, mechanical properties and degradation behavior of as cast $\mathrm{Mg}-4 \mathrm{wt} \% \mathrm{Zn}$ alloy. The evaluation process was conducted using optical and scanning electron microscopy, X-ray diffraction, tensile and compression tests, in addition to a corrosion study by immersing in simulated body fluid (SBF). Results showed that $\mathrm{Sb}$ refines the grain size of the base alloy and also enhances its mechanical properties and degradation rate as well. These were due to the formation of the secondary phase of $\mathrm{Mg}_{3} \mathrm{Sb}_{2}$. To get better degradation rate, the Mg- $4 \mathrm{wt} \% \mathrm{Zn}$ and $\mathrm{Mg}-4 \mathrm{wt} \% \mathrm{Zn}-0.5 \mathrm{wt} \% \mathrm{Sb}$ alloys are coated with Ca-P using autocatalytic technique. The results demonstrated that the formed coat layer improves the degradation rate of samples under the condition of this study. The current study shows that $\mathrm{Mg}-4 \mathrm{wt} \% \mathrm{Zn}-0.5 \mathrm{wt} \% \mathrm{Sb}$ alloy has good mechanical properties and when it coated by $\mathrm{Ca}-\mathrm{P}$, it gave a better corrosion resistance that makes it ideal for biodegradable medical application.
\end{abstract}




\section{Graphical Abstract}
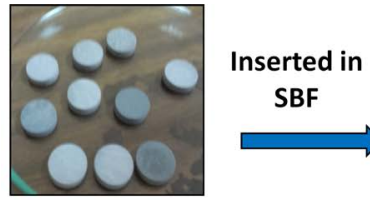

SBF
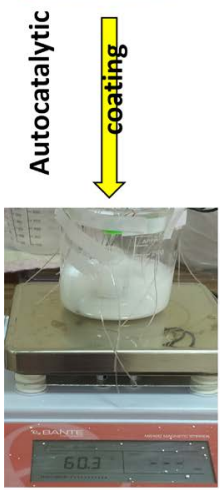

Inserted in

SBF

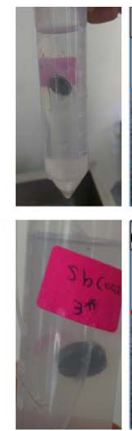

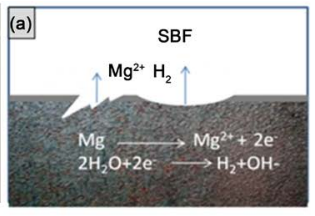
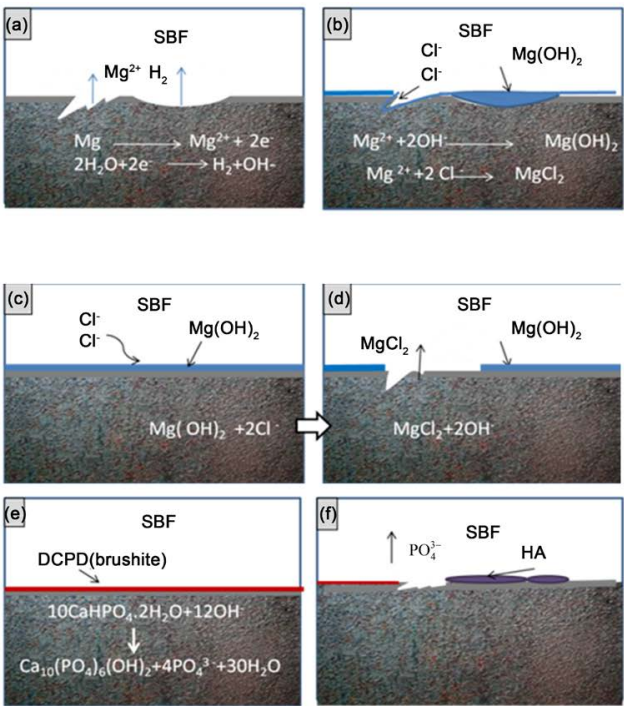

\section{Keywords}

Mg Alloy, Mechanical Properties, Autocatalytic Route, Degradation Rate, Calcium Phosphate Coating

\section{Introduction}

Recently biodegradable metallic implants have notable consideration in biomaterial field. Their degradation after a certain time, leads to reduce the call for extra surgery to remove the short-term implant. $\mathrm{Mg}$ alloy has a great interest as a biodegradable implant because its biocompatibility as it found naturally in bone; it can directly influence bone-resorbing cells and consider as a vital factor for bone metabolism. Many clinical in vivo and in vitro studies have been recommended Mg-base implants due to their good biocompatibility and their mechanical properties comparable with those of natural bone [1] [2]. The Mg density is $\left(1.7-2.0 \mathrm{~g} / \mathrm{cm}^{3}\right)$ which is a slightly lower than that of natural bone (1.8 $2.1 \mathrm{~g} / \mathrm{cm}^{3}$ ), and its elastic modulus (41-45 GPa) is closer to those of the human bone (10 - $40 \mathrm{GPa}$ ) [3]. All these properties reduce the probability of stress shielding effect observed in the case of higher modulus materials such as titanium alloys [4]. Unfortunately, the application of magnesium as an implant has some restrictions such as its high degradation rate, especially in an aggressive chloride medium like a human body. This implant may degrade and reduce its mechanical properties before new tissues are completely healed [5]. Hence element alloying and surface modification are effective methods to improve rapid degradation of $\mathrm{Mg}$ and also to enhance their mechanical properties besides aiding in decrease corrosion.

Many elements such as $\mathrm{Ca}, \mathrm{Mn}, \mathrm{Al}, \mathrm{Zn}, \mathrm{Si}$, and $\mathrm{Sr}$ are used as alloying ele- 
ments with magnesium. In the present research, zinc ( $\mathrm{Zn})$ and antimony $(\mathrm{Sb})$ were chosen as alloying elements. $\mathrm{Zn}$ is a commonly used as alloying element with magnesium and its strengthening effect is only following aluminum. It furthermore assists to eliminate the harmful effect of impurities such as iron and nickel, thus improving the corrosion resistance of magnesium alloys [6]. Also, $4 \mathrm{wt} \% \mathrm{Zn}$ which was chosen in this work was reported to be the optimum $\mathrm{Zn}$ content for tensile and mechanical strengthening over the range of alloying [7]. Moreover, zinc is vital for many biological functions, plays a fundamental role in the metabolic activities of the body's enzymes, essential for cell division and the creation of protein and DNA. Whereas excessive exposure toxicity of $\mathrm{Zn}$ is rare, $\mathrm{Zn}$ shortage has a harmful effect on growth, neuronal development, and immunity [4]. On the other hand, it is reported that the addition of $0.4 \mathrm{wt} \% \mathrm{Sb}$ gives high mechanical properties, however, at the higher Sb level of $0.7 \mathrm{wt} \%$ the strength and hardness decrease [8]. Therefore, in present work, $0.5 \mathrm{wt} \% \mathrm{Sb}$ is added to $\mathrm{Mg}-4 \mathrm{wt} \% \mathrm{Zn}$ alloy to study its effect on mechanical properties and degradation behavior. On the other hand the biological effect of Sb still needs more experimental research.

To improve corrosion resistance and biocompatibility of prepared alloys, the surface will be coated with Ca-P layer. $\mathrm{Ca}$ and $\mathrm{P}$ are the major elements in bone minerals. Thus, Ca-P coatings, especially osteoconductive minerals such as hydroxyapatite (HA) and tricalcium phosphate (TCP), should be useful in constructing new bone and promoting osteointegration around $\mathrm{Mg}$ implants [9]. Niu, Jialin, et al. [10] reported that the Ca-P coat improves the corrosion resistance of $\mathrm{Mg}-\mathrm{Nd}-\mathrm{Zn}-\mathrm{Zr}$ alloy and reduced the hemolysis rate from $48 \%$ to $0.68 \%$. Song, Yang, et al. [9] showed that both the HA and FHA (fluoridated hydroxyapatite) coating could promote the nucleation of osteoconductive minerals (bone-like apatite or $\beta$-TCP), while the precipitates on the uncoated Mg-Zn alloy in modified simulated biological fluid had low $\mathrm{Ca} / \mathrm{P}$ molar ratios, which delayed bone-like apatite formation.

Several coating techniques have been investigated, but due to the special properties of $\mathrm{Mg}$ as high reactivity and relatively low melting point $\left(650^{\circ} \mathrm{C}\right)$, not all coating procedures can be suitable for $\mathrm{Mg}$ [11]. Seeing that the biomimetic coating would be helpful in coating biodegradable substrates such as $\mathrm{Mg}$-alloys, it reduces the incubation times in SBF during the coating procedure [12]. As reported this resulted in the formation of non-uniform and porous Ca-P coating on Mg substrates [13], in addition to hydrogen bubbles formed on the Mg surface during immersion. When using a Sol gel technique for Mg substrates, the temperatures should be less than the melting point of pure $\mathrm{Mg}\left(650^{\circ} \mathrm{C}\right)$ [14] to avoid affecting the surface integrity of the $\mathrm{Mg}$ substrate. Accordingly, in the present work autocatalytic technique which reported in previous studies [15] [16] [17] is used. This technique is simple, economical, does not require high temperature and setup in short time which minimize the chance of degradation.

So as there is little information on $\mathrm{Mg}-\mathrm{Zn}-\mathrm{Sb}$, as biodegradable implant, the 
present work aims to study the effect of Sb addition on microstructure, mechanical and degradation behavior of $\mathrm{Mg}-4 \mathrm{wt} \% \mathrm{Zn}$ alloy. Also, we intend to study the effect of the autocatalytic technique on degradation to get an appropriate alloy for load bearing medical applications.

\section{Material and Methods}

\subsection{Material Preparation}

The base composition of the studied alloy was $\mathrm{Mg}-4 \mathrm{wt} \% \mathrm{Zn}$. $0.5 \mathrm{wt} \% \mathrm{Sb}$ was added to the base alloy in order to investigate its effect on microstructure, mechanical properties and the degradation rate. The alloy was prepared from commercial pure Mg (99.8 wt\% purity), Zn (99.98 wt\% purity), and Sb (99.99 wt $\%$ purity). Before melting process a charge calculations are performed and with respect to experience, the $90 \%$ efficiency of melting process and $10 \%$ losses during melting can be estimated and be in consideration. After that melting the charge of about $1.5 \mathrm{~kg}$ of each alloy in a graphite crucible placed in an electric resistance furnace. The melting and pouring processes were carried out under gas mix consists of tetrafluoroethane $\left(\mathrm{CF}_{3} \mathrm{CH}_{2} \mathrm{~F}, \mathrm{HFC}-134 \mathrm{a}, 1\right.$ vol.\%) and carbon dioxide $\left(\mathrm{CO}_{2}\right.$, Bal.). Firstly, commercial $\mathrm{Mg}$ ingots were melted to above $650^{\circ} \mathrm{C}$, and then $\mathrm{Zn}$ with melting point $419^{\circ} \mathrm{C}$ was added into $\mathrm{Mg}$ melt. After that, the melt were heated to about $720^{\circ} \mathrm{C}$, and then $\mathrm{Sb}$ with melting point $630^{\circ} \mathrm{C}$ was added into $\mathrm{Mg}$ melt. The melt was manually stirred for $3 \mathrm{~min}$ using a stainless steel rod, and then was held for additional $15 \mathrm{~min}$ in order to get full homogenization. Before pouring the melt, test sample of the melt is required to make a chemical analysis correction using X-ray fluorescence (XRF) analyzer. Depending on the test result a correction process is required either by diluting (adding pure $\mathrm{Mg}$ ) or concentrating (adding alloying element as $\mathrm{Sb}$ or $\mathrm{Zn}$ or both) to get the required alloy composition. After that, the slag was removed, and then the melt was poured at about $720^{\circ} \mathrm{C}$ into a preheated cast iron mold up to $100^{\circ} \mathrm{C}$ with dimensions of outer diameter $(100 \mathrm{~mm})$, inner diameter $(50 \mathrm{~mm})$ and length $(250$ $\mathrm{mm}$ ). The chemical compositions of the prepared alloy were determined by using $\mathrm{X}$-ray fluorescence (model Axios advanced-PANALYTCAL, The Netherlands).

\subsection{Microstructure Characterization}

All metallographic specimens were cut at the same position of $10 \mathrm{~mm}$ from the bottom of castings. Grinding of the specimens were carried out on wet SiC papers, down to grit size 1200 then followed by fine polishing with diamond, particle size from 1 to $6 \mu \mathrm{m}$, on nylon cloth, rinsing with water and ethyl alcohol. For best results, the polished surface must be mirror like, i.e., free from any residual layer. After that, the specimens are etched by solution with $10 \mathrm{ml}$ nitric acid, $30 \mathrm{ml}$ acetic acid, $40 \mathrm{ml}$ water, and $120 \mathrm{ml}$ ethanol for $2-3 \mathrm{~min}$ [18].

The microstructures of the specimens were analyzed by optical microscope (OM) (Zeis model Axiotech, Germany). Six OM micrographs were taken for each sample from the observed area at a magnification of $100 \times$. The average 
grain size of $\alpha$-Mg was measured by using an image analyzer. All $\alpha$-Mg grains existed in one picture taken from the observed area were measured.

Phase constituents of samples were analyzed by X-ray diffraction (XRD) (model X'PERT PRO, The Netherlands) using $\mathrm{Cu}-\mathrm{K} \alpha(\mathrm{K}=1.54056 \AA)$ radiation in step scan of $2 \theta$ from $20^{\circ}$ to $80^{\circ}$ with an increment of $0.02^{\circ}$ and a scanning speed of $4 \%$ min. Scanning electron microscope (Inspect S50.Fel, The Netherlands) equipped with an energy dispersive X-ray spectrometer (EDS) were used to conduct microstructure analysis.

\subsection{Mechanical Tests}

Tensile and compression tests were carried out using LFM-L-20KN Computer controlled and digital display electromechanical universal testing machine (model LFM-L-20KN (bench top), Switzerland). The dimensions of a cylindrical tensile specimen are shown in Figure 1 according to ASTM E8M [19]. Three specimens were tested with a strain rate of $0.1 \mathrm{~mm} / \mathrm{min}$ for each alloy. Cylindrical samples with a diameter of $10 \mathrm{~mm}$ and a height of $8 \mathrm{~mm}$ were used for the compression test.

\subsection{Sample Coating}

\subsubsection{Pre-Treatment}

Before coating, samples were cut into discs $(10 \mathrm{~mm}$ diameter and $2 \mathrm{~mm}$ thickness). Each sample was cleaned with acetone, $70 \%$ ethanol, and finally distilled water for 15 min each, in an ultrasonic cleaner. Then samples were etched in Kroll's reagents for $10 \mathrm{~min}$ at $20^{\circ} \mathrm{C}$ next washed with distilled water to remove the native oxide surface. Afterward, samples were immersed in $10 \mathrm{M} \mathrm{NaOH}$ bath at $60^{\circ} \mathrm{C}$ for $24 \mathrm{~h}$ followed by heating and holding at $100^{\circ} \mathrm{C}$ for $1 \mathrm{~h} \mathrm{[15]} \mathrm{[16]} \mathrm{[17].}$

\subsubsection{Coating by Autocatalytic Bath}

After the pretreatment step, samples were immersed in an acidic autocatalytic bath under magnetic stirrer for $2 \mathrm{~h}$ at $60^{\circ} \mathrm{C} \pm 2^{\circ} \mathrm{C}$ at $\mathrm{pH} 5$ to get different phases Ca-P coatings on samples. The composition of acidic bath was reported in previous work [15] [16] [17].

\subsubsection{Characterization of Coating}

Surface morphology and the chemical compositions of the deposited layer were analyzed by field emission scanning electron microscope (Quanta 250) with EDS. Structure of coated layer was analyzed by X-ray diffraction (XRD) with similar condition used for microstructure composition.

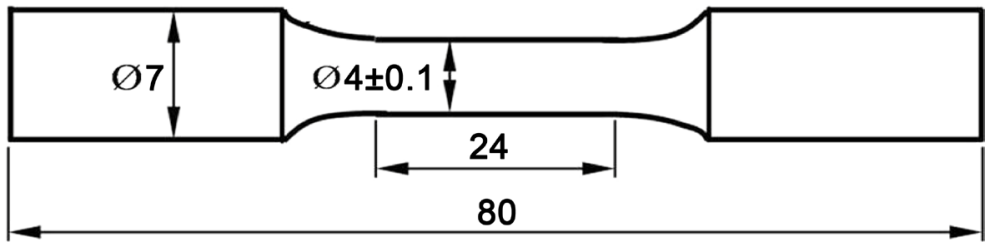

Figure 1. Dimensions of the tensile specimen (mm) [19]. 


\subsection{Corrosion Evaluation by Immersion in Simulated Body Fluid (SBF)}

Corrosion resistance by in vitro degradation method was obtained by weight loss measurements which were performed by immersing the alloy samples in SBF. The chemical composition of c-SBF in comparison to human blood plasma was reported in several studies [20]. The $\mathrm{pH}$ value of the initial solution was adjusted to 7.4. The whole test cell was maintained at $37^{\circ} \mathrm{C} \pm 1^{\circ} \mathrm{C}$ in a shaking water bath to prevent aggregation of the precipitates on sample surfaces [15]. In this test two categories of samples (non-coated (bare), coated) were studied. The samples were immersed for 14 days in SBF solution with refreshment after 3 days. The refreshment was done to simulate the metabolic environment of the human body and study the formed layer. The appearance and microstructure of the specimens were characterized by SEM with EDS. The $\mathrm{pH}$ value of the solution was measured by a $\mathrm{pH}$ meter with an accuracy of \pm 0.01 .

The sample weight was measured every 24 hours of immersion after removal of corrosion products with a chromic acid. The degradation rates were calculated by the following equation according to the standard:

$$
D R=\frac{\Delta m}{A T \rho}
$$

where: $D R$ is the degradation rate $(\mathrm{mm} / \mathrm{hr}), \Delta m$ is the mass loss $(\mathrm{g}), A$ is the initial surface area exposed to the SBF $\left(\mathrm{mm}^{2}\right), T$ is the immersion time (hr), and $\rho$ is the density of tested sample $\left(\mathrm{g} / \mathrm{mm}^{3}\right)$.

The concentrations of $\mathrm{Ca}$ and $\mathrm{P}$ ions in SBF after immersion of coated $\mathrm{Mg}-4 \mathrm{wt} \% \mathrm{Zn}$ and $\mathrm{Mg}-4 \mathrm{wt} \% \mathrm{Zn}-0.5 \mathrm{wt} \% \mathrm{Sb}$ for 14 days were measured using a $\mathrm{UV}-\mathrm{V}$ is spectrophotometer and the specific kits (Biodiagnostic, Diagnostic and research reagents, Egypt) at wavelength $640 \mathrm{~nm}, 585 \mathrm{~nm}$ for phosphorus and calcium respectively.

\section{Results}

\subsection{Chemical Composition}

The chemical compositions of the prepared alloy were determined using X-ray fluorescence (XRF) analyzer. Table 1 showed the obtained chemical composition of the investigated alloys.

\subsection{Phases and Microstructure Characterization}

Figure 2 shows the XRD results and the optical microstructure of the as-cast prepared alloys. As shown in Figure 2(a), $\alpha$-Mg and MgZn phases are the only

Table 1. The chemical composition of the prepared alloys (wt\%).

\begin{tabular}{cccccc}
\hline Prepared alloy & $\mathrm{Mg}$ & $\mathrm{Zn}$ & $\mathrm{Sb}$ & $\mathrm{Fe}$ & $\mathrm{Cu}$ \\
\hline Mg-4Zn & 96.012 & 3.95 & - & 0.007 & 0.031 \\
Mg-4Zn-0.5Sb & 95.575 & 3.91 & 0.466 & 0.016 & 0.033 \\
\hline
\end{tabular}



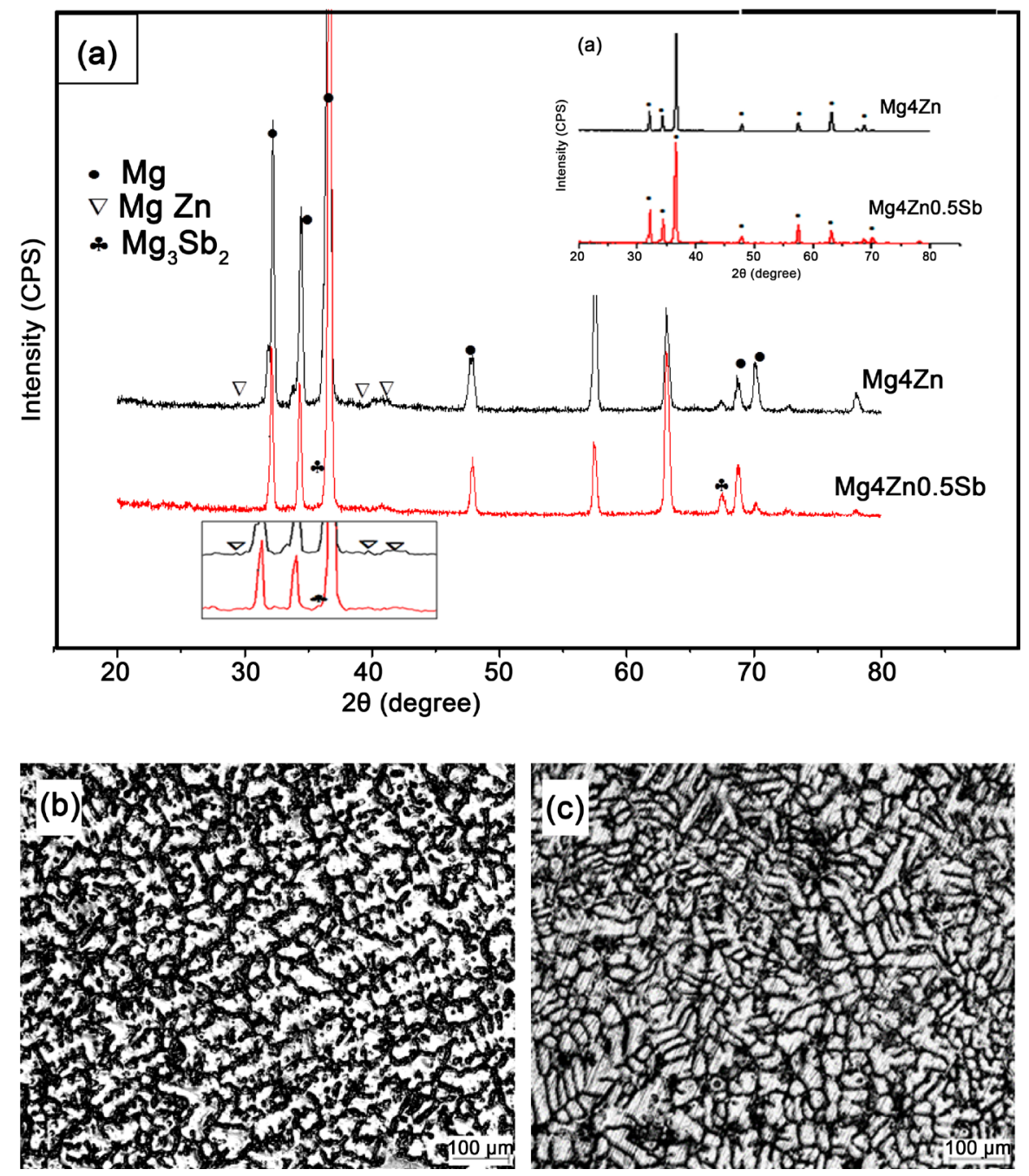

Figure 2. (a) XRD patterns of as-cast alloys Mg- $4 \mathrm{wt} \% \mathrm{Zn}$ and $\mathrm{Mg}-4 \mathrm{wt} \% \mathrm{Zn}-0.5 \mathrm{wt} \% \mathrm{Sb}$, optical micrographs of as-cast alloys (b) Mg- $4 \mathrm{wt} \% \mathrm{Zn}$ and (c) Mg- $4 \mathrm{wt} \% \mathrm{Zn}-0.5 \mathrm{wt} \% \mathrm{Sb}$.

constituents of the Mg-4wt\% $\mathrm{Zn}$ alloy. These two phases have also been reported to exist in the as-cast microstructure of an $\mathrm{Mg}-4 \mathrm{wt} \% \mathrm{Zn}$ alloy [22]. In the $\mathrm{Sb}$ containing materials, however, some new peaks corresponding to the $\mathrm{Mg}_{3} \mathrm{Sb}_{2}$ intermetallic phase appear in the patterns. Figure 2(b) \& Figure 2(c) show that the coarse dendritic structure of the $\mathrm{Mg}-4 \mathrm{wt} \% \mathrm{Zn}$ alloy is generally refined from about $100 \mu \mathrm{m}$ (Figure 2(b)) to about $53 \mu \mathrm{m}$ after the addition of $0.5 \mathrm{wt} \% \mathrm{Sb}$ (Figure 2(c)).

For clear observations of the constitutive phases, SEM micrographs with EDS and elemental mapping of $\mathrm{Mg}, \mathrm{Zn}$ and $\mathrm{Sb}$ of investigated alloys are shown in Figure 3 \& Figure 4, respectively. Figure 3(a) shows the microstructure of the $\mathrm{Mg}-4 \mathrm{wt} \% \mathrm{Zn}$ alloy which consists of the primary $\alpha$-Mg matrix (region A), while the second phase appears as white island-like (region B) which was identified by EDS to be composed of $\mathrm{Mg}$ and $\mathrm{Zn}$ elements. Combined with the XRD results shown in Figure 2(a), it is found that the island-like particles are most likely the MgZn particles and thus the lamellar eutectic structure consists of $\alpha-\mathrm{Mg}+$ 

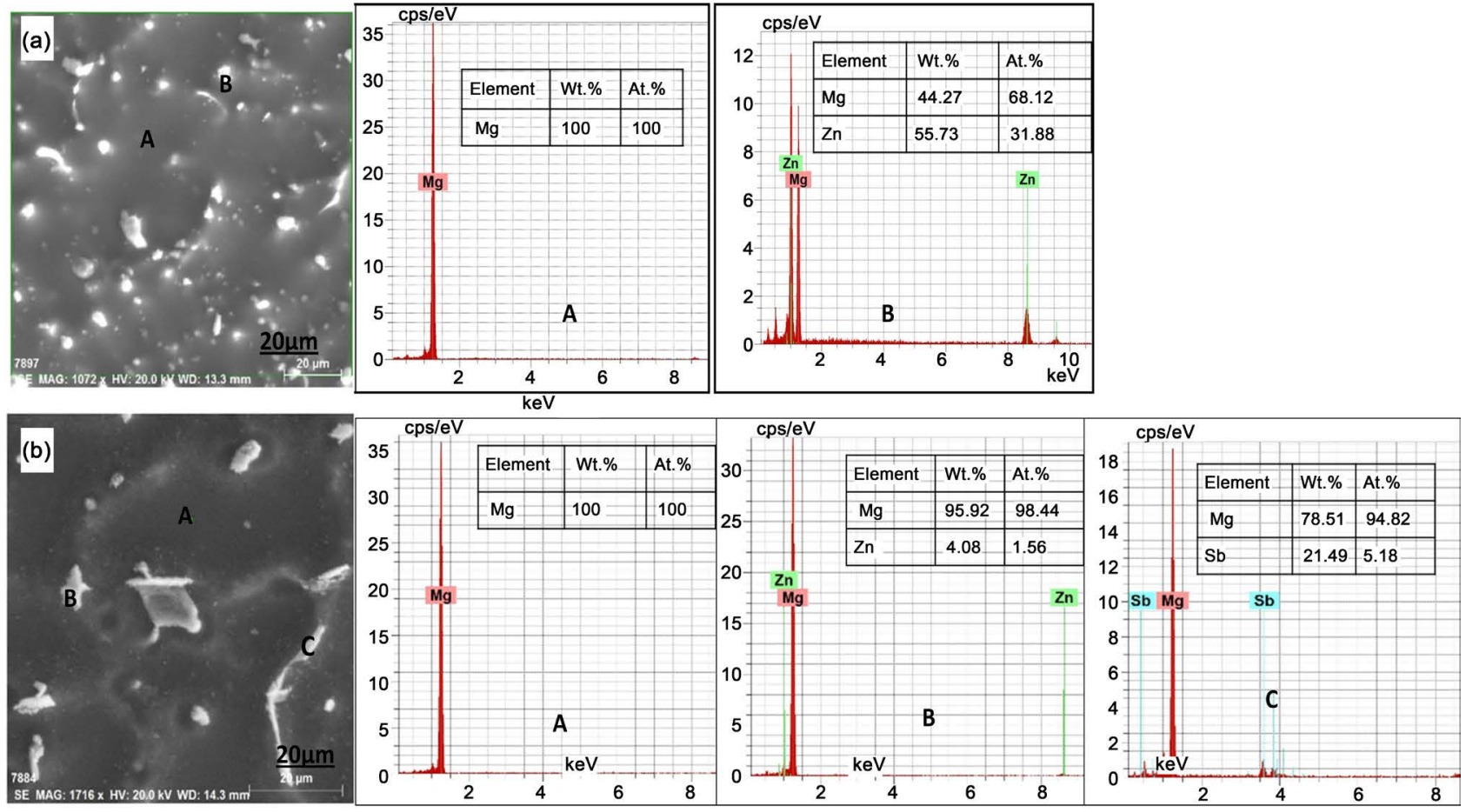

Figure 3. SEM micrographs with EDS showing intermetallic phases in as-cast alloys (a) $\mathrm{Mg}-4 \mathrm{wt} \% \mathrm{Zn}$ and (b) Mg-4wt\% $\mathrm{Zn}-0.5 \mathrm{wt} \% \mathrm{Sb}$.
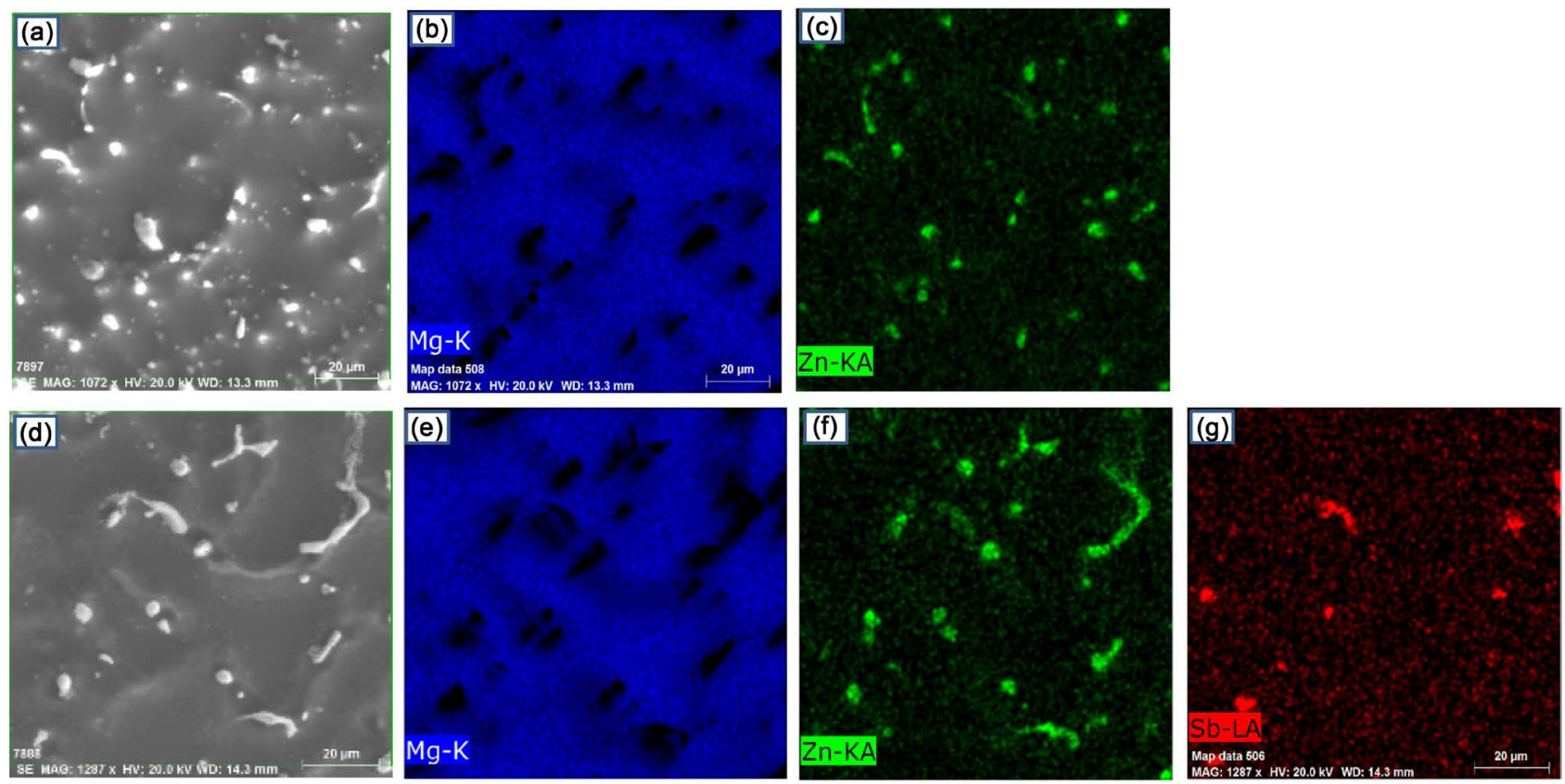

Figure 4. (a) SEM micrograph and EDS elemental mapping of (b) Mg and (c) Zn in as-cast alloy Mg-4wt\% Zn and (d) SEM micrograph and EDS elemental mapping of (e) Mg, (f) Zn and (g) Sb in as-cast alloy Mg-4wt\% Zn-0.5wt\% Sb.

MgZn. In Sb-added alloy (Figure 3(b)), a new rod shape particles contain Mg and $\mathrm{Sb}$ is appeared (region $\mathrm{C}$ ) which was detected by $\mathrm{XRD}$ as $\mathrm{Mg}_{3} \mathrm{Sb}_{2}$ (Figure $2(a))$.

Figure 4 shows EDS elemental mapping of $\mathrm{Mg}, \mathrm{Zn}$ and $\mathrm{Sb}$ in the investigated 
alloys. It can be seen that the non-uniform distribution of $\mathrm{Zn}$ (Figure 4(c)) in the interdendritic regions of $\alpha$ - Mg (Figure 4(b)). With addition of $0.5 \mathrm{wt} \% \mathrm{Sb}$, the distribution of $\mathrm{Sb}$ is mostly at the boundaries of the $\alpha$ - Mg dendrites (Figure $4(\mathrm{~g})$ ) and the uniform distribution of $\mathrm{Zn}$ at dendrites boundaries (Figure 4(f)).

\subsection{Mechanical Properties}

The ultimate tensile strength, elongation and Compressive strength of investigated alloys, are summarized in Table 2.

\subsection{Characterization of Coating}

It is observable that autocatalytic bath changes the morphologies of the based alloys as shown in Figure 5. Homogeneous coating was observed for both alloys. At higher magnification it was found that bulk coating was formed after immersion of $\mathrm{Mg}-4 \mathrm{wt} \% \mathrm{Zn}$ in the bath with distribution of white grain on its surface (Figure 5(b)). EDS analysis of this layer demonstrates the presence of $\mathrm{Mg}, \mathrm{O}$

Table 2. The ultimate tensile strength, elongation and Compressive strength of investigated alloys.

\begin{tabular}{cccc}
\hline Material & $\begin{array}{c}\text { Ultimate tensile strength, } \\
\text { MPa }\end{array}$ & Elongation\% & $\begin{array}{c}\text { Compressive strength, } \\
\text { MPa }\end{array}$ \\
\hline Cortical bone [28] & 135 & $1.07-2.10$ & $164-240$ \\
Pure Mg [29] & 97 & 7 & 185.4 \\
Mg-4Zn & 100.70 & 8 & 222.5 \\
Mg-4Zn-0.5Sb & 185 & 6.88 & 268.5 \\
\hline
\end{tabular}
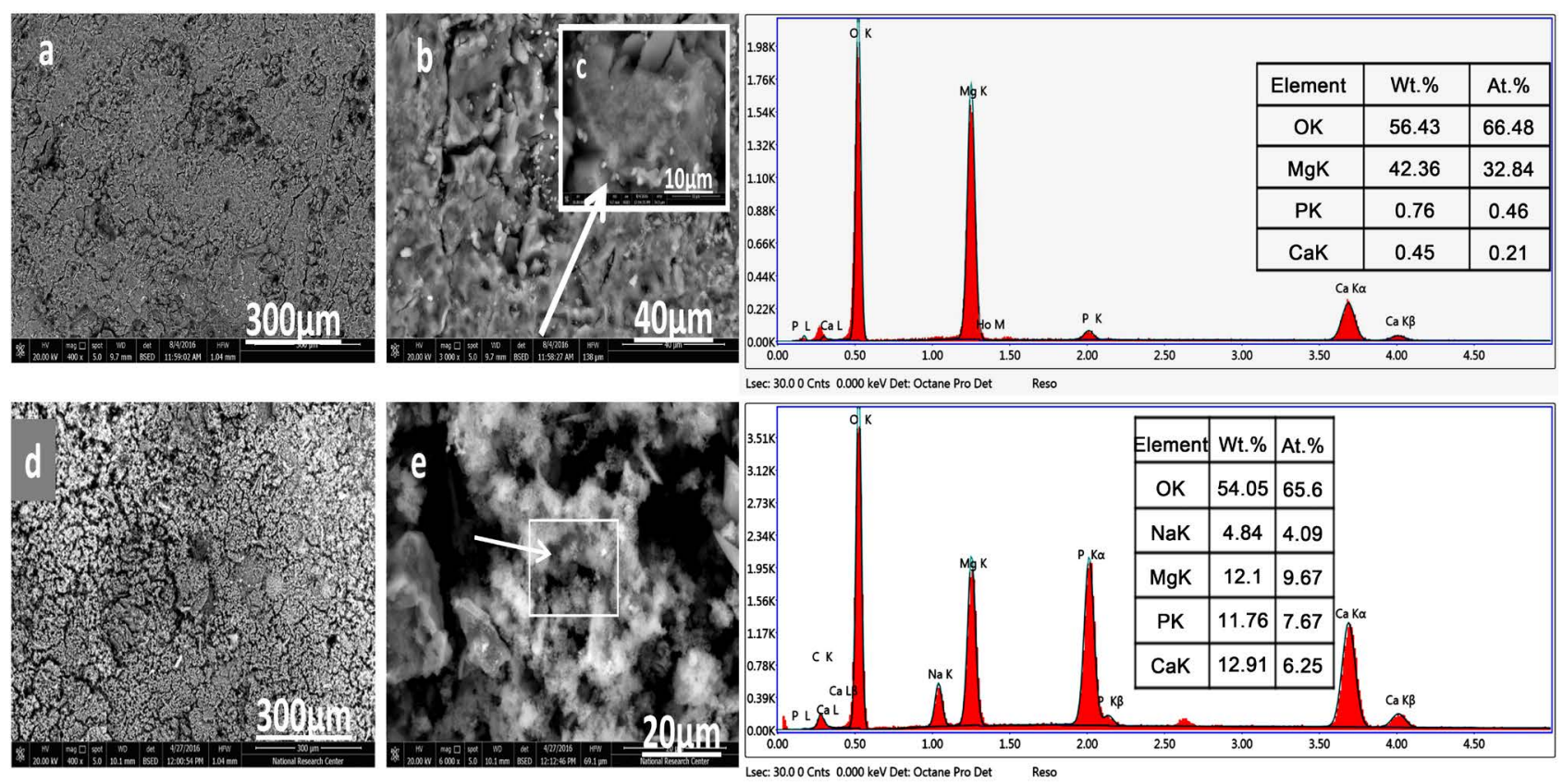

Figure 5. SEM micrographs with EDS showing the coat formed on the surface of Mg-4wt\% Zn ((a)-(c)), Mg- $4 \mathrm{wt} \% \mathrm{Zn}-0.5 \mathrm{wt} \% \mathrm{Sb}$ $((\mathrm{d}),(\mathrm{e}))$. 
with traces of phosphorus and calcium on the surface of the alloy (Figure 5(c)). While after addition of $\mathrm{Sb}$, an agglomerate of fine grains covers the surface of the alloys (Figure 5(e)). EDS of this layer consist of higher amount of $\mathrm{Ca}, \mathrm{P}$ in addition to $\mathrm{Na}$ ions. The addition of $\mathrm{Sb}$ allows the precipitation of $\mathrm{Ca}-\mathrm{P}$ layer as a nucleation for hydroxyapatite (HA). The atomic calcium phosphate ratio $\mathrm{n}(\mathrm{Ca}) / \mathrm{n}(\mathrm{P})$ value suggest that formed layer may be dicalcium Phosphate dihydrate (DCPD), also known as brushite which act as a precursor phase.

The XRD patterns Mg- $4 \mathrm{wt} \% \mathrm{Zn}$ and $\mathrm{Mg}-4 \mathrm{wt} \% \mathrm{Zn}-0.5 \mathrm{wt} \% \mathrm{Sb}$ alloys after coating (Figure 6) show existence of $\mathrm{Mg}(\mathrm{OH})_{2}$ peaks which confirmed by SEM results. It is noted that $\mathrm{Mg}-4 \mathrm{wt} \% \mathrm{Zn}$ displays high intensity of $\mathrm{Mg}(\mathrm{OH})_{2}$ peaks compared with $\mathrm{Mg}-4 \mathrm{wt} \% \mathrm{Zn}-0.5 \mathrm{wt} \% \mathrm{Sb}$.

Other than brushite phase cannot be detected by XRD as it is very thin and non uniform layer. Improvement of the formed layer will be considered in future work by increasing the immersion time and $\mathrm{pH}$ of autocatalytic bath.

\subsection{Corrosion Evaluation by Immersion in Simulated Medium}

The average mass loss and the rate of degradation of Mg-4wt\% $\mathrm{Zn}$ and $\mathrm{Mg}-4 \mathrm{wt} \%$ $\mathrm{Zn}-0.5 \mathrm{wt} \% \mathrm{Sb}$ alloys before and after coating during 14 days of immersion in SBF are illustrated in Figure 7.

The change in mass is an indicator for the degradation of the alloy samples. Figure 7 illustrates that, the coated sample of $\mathrm{Mg}-4 \mathrm{Zn}$ showed the lowest rate of degradation in the first $24 \mathrm{hr}$ of immersion. As the sample has a porous, and

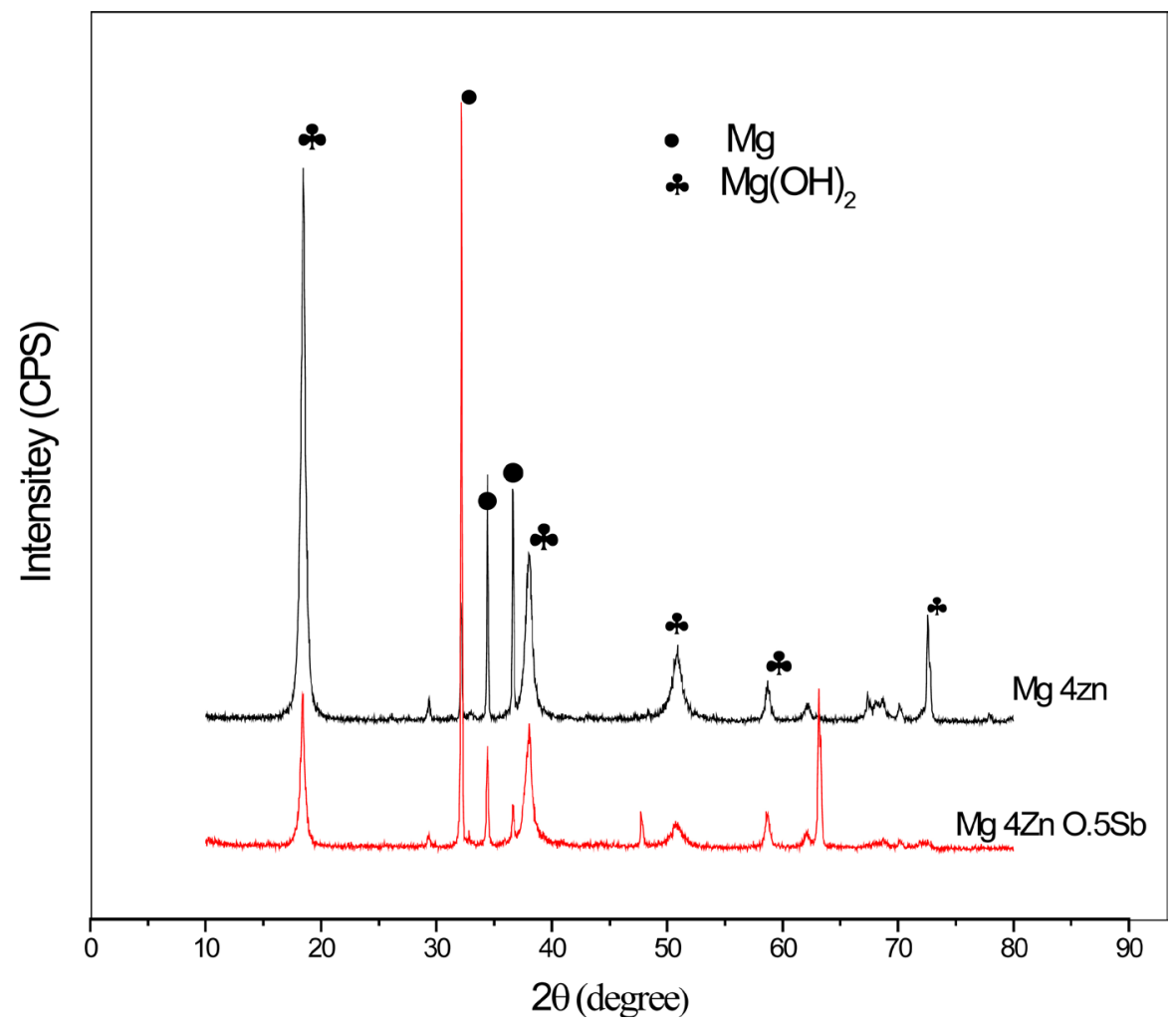

Figure 6. XRD patterns of Mg- $4 \mathrm{wt} \% \mathrm{Zn}$ and $\mathrm{Mg}-4 \mathrm{wt} \% \mathrm{Zn}-0.5 \mathrm{wt} \%$ Sb samples after coating. 


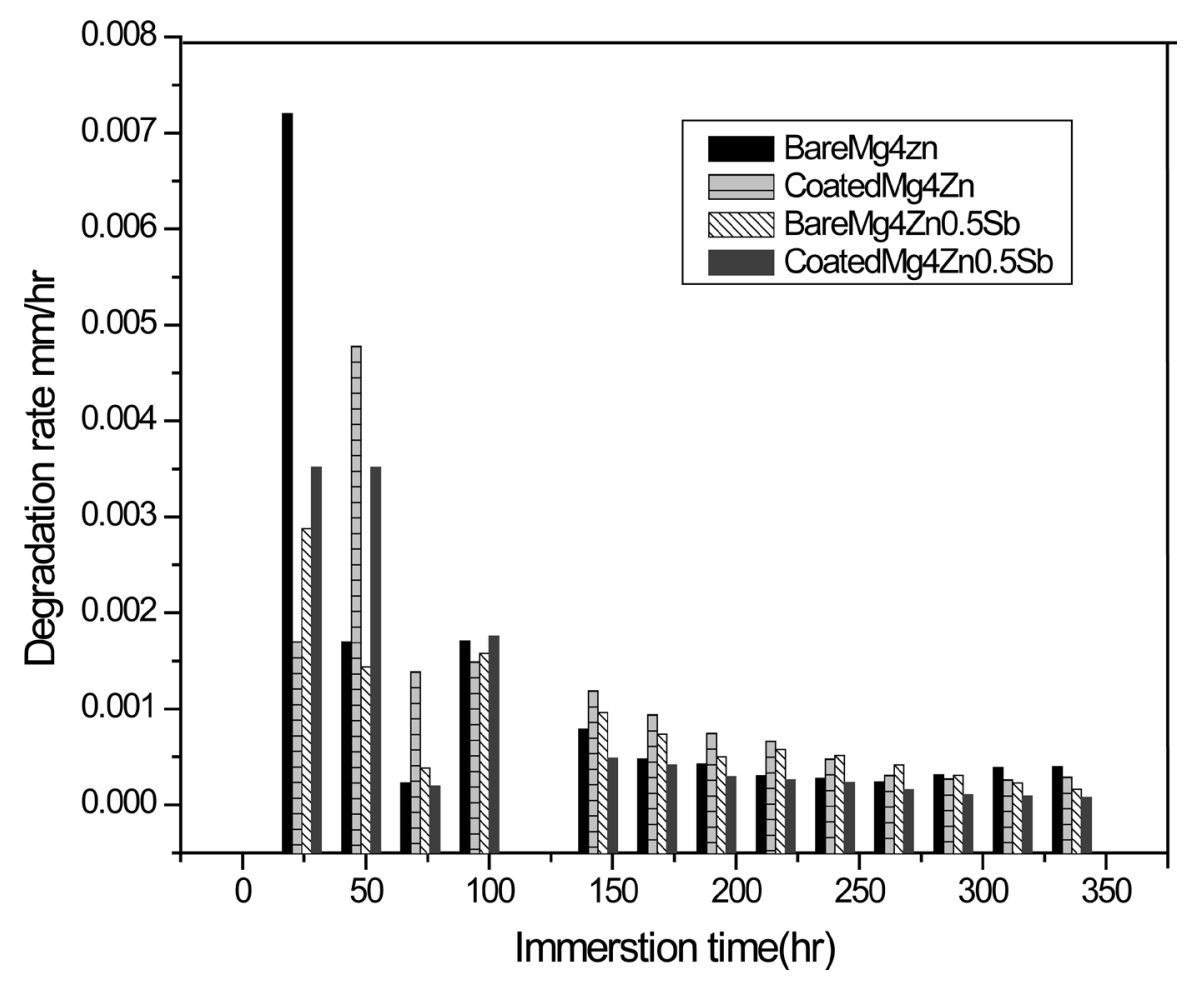

Figure 7. The degradation rate during immersion of coated and bare alloys of $\mathrm{Mg}-4 \mathrm{Zn}$ and $\mathrm{Mg}-4 \mathrm{Zn}-0.5 \mathrm{Sb}$.

dense layer of $\mathrm{Mg}(\mathrm{OH})_{2}$, which can reduce the corrosion rate. However, more than $48 \mathrm{hr}$ of immersion, the degradation rate of both coated samples increased. As the protective $\mathrm{Mg}(\mathrm{OH})_{2}$ layer converted into a more soluble $\mathrm{MgCl}_{2}$. This will cause the coated $\mathrm{Mg}-4 \mathrm{Zn}$ alloys to expose to the solution and stimulate the degradation. As well, the coated $\mathrm{Mg}-4 \mathrm{Zn}-0.5 \mathrm{Sb}$ sample displayed high rate of degradation due to dissolving of brushite coat. On the other hand, the degradation rate of the bare samples of $\mathrm{Mg}-4 \mathrm{Zn}$ and $\mathrm{Mg}-4 \mathrm{Zn}-0.5 \mathrm{Sb}$ decreased due to formation of $\mathrm{Mg}(\mathrm{OH})_{2}$ protective layer.

By refreshing the solution after 3 days of immersion, it is found that, the degradation rate increased again for all the samples. This caused by $\mathrm{Cl}^{-}$ions which accelerate the electrochemical reaction rate from magnesium and leads to more degradation of the Mg matrix. Seeing that the exposure period continues, the corrosion rate reached a steady state as the rate of formation of $\mathrm{Mg}(\mathrm{OH})_{2}$ is equal to destruction of it by $\mathrm{MgCl}_{2}$. At the end of immersion time it is observed that the $\mathrm{Mg}-4 \mathrm{Zn}-0.5 \mathrm{Sb}$ samples shows the lowest rate of degradation specially the coated one.

Figure 8 shows the micrograph of the surface of $\mathrm{Mg}-4 \mathrm{Zn}$ and $\mathrm{Mg}-4 \mathrm{Zn}-0.5 \mathrm{Sb}$ alloys after immersion in the SBF solution for $336 \mathrm{~h}$. Figure 8(a), Figure 8(d), Figure $8(\mathrm{~g})$, and Figure $8(\mathrm{j})$ ) show the surface cracks which formed from dehydration of the surface layer in the air [23]. Existence of cracks accelerates corrosion of the substrate by making solution come into contact with the matrix [24]. The bare $\mathrm{Mg}-4 \mathrm{Zn}$ alloy and $\mathrm{Mg}-4 \mathrm{Zn}-0.5 \mathrm{Sb}$ (Figure 8(a), Figure 8(g)) showed deeper 

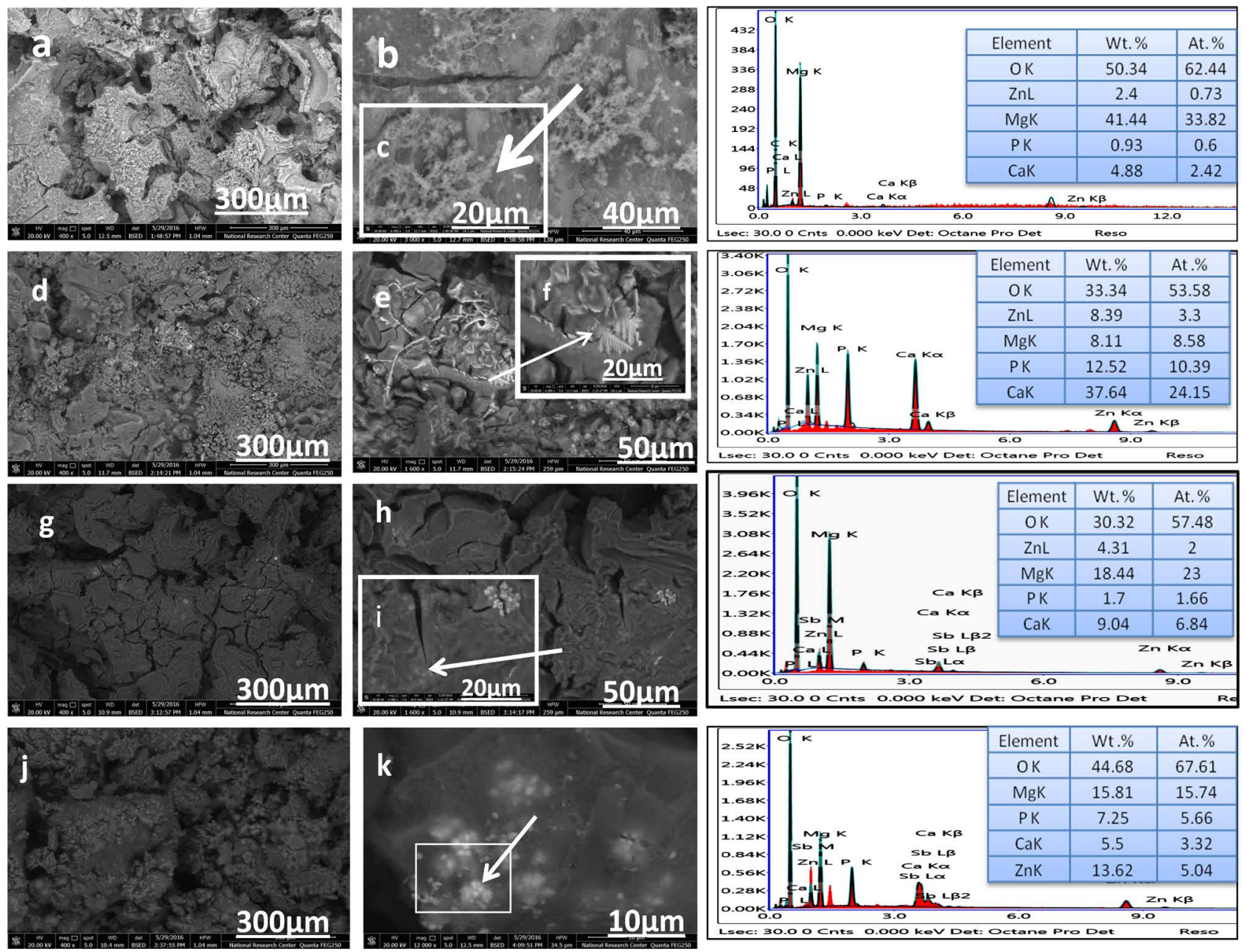

Figure 8. SEM micrographs of samples surface after SBF immersion. ((a)-(c)) bare Mg-4Zn, ((d)-(f)) coated Mg-4Zn, ((g)-(i)) bare $\mathrm{Mg}-4 \mathrm{Zn}-0.5 \mathrm{Sb},((\mathrm{j}),(\mathrm{k}))$ coated $\mathrm{Mg}-4 \mathrm{Zn}-0.5 \mathrm{Sb}$.

and thicker cracks than coated alloys (Figure $8(\mathrm{~d})$, Figure $8(\mathrm{j})$ ). The EDS analysis showed the presence of $\mathrm{Mg}(\mathrm{OH})_{2}$ consistent with the atomic ratio of $\mathrm{Mg}$ to $\mathrm{O}$ (1:2) on the surface of bare Mg-4Zn (Figure $8(\mathrm{c})$ ). The EDS results of the corroded layer on coated samples (Figure $8(\mathrm{f}$ ), Figure $8(\mathrm{k})$ ) showed the existence of $\mathrm{Mg}$ and $\mathrm{O}$ as well as amounts of $\mathrm{Ca}$ and $\mathrm{P}$, which represents formation of HA. As observed in EDS results that the bare samples have trace amounts of $\mathrm{Ca}$ and $\mathrm{P}$ in compare with the coated samples.

This consequence points that the coated samples are more successful to form nucleation of Ca-P which initiates the formation of HA. To confirm that, the concentrations of $\mathrm{Ca}$ and $\mathrm{P}$ ions in SBF after immersion of coated $\mathrm{Mg}-4 \mathrm{Zn}$ and $\mathrm{Mg}-4 \mathrm{Zn}-0.5 \mathrm{Sb}$ for 14 days are measured as presented in Figure 9.

\section{Discussion}

It is illustrious that the difference in the electronegativity values between $\mathrm{Mg}$ of $1.31, \mathrm{Zn}$ of 1.6 and $\mathrm{Sb}$ of 2.05 , provides the $\mathrm{Sb}$ more tendencies to form a compound with Mg than with $\mathrm{Zn}$ [8] [25]. Therefore, all of the Sb added to Mg-4wt\% 


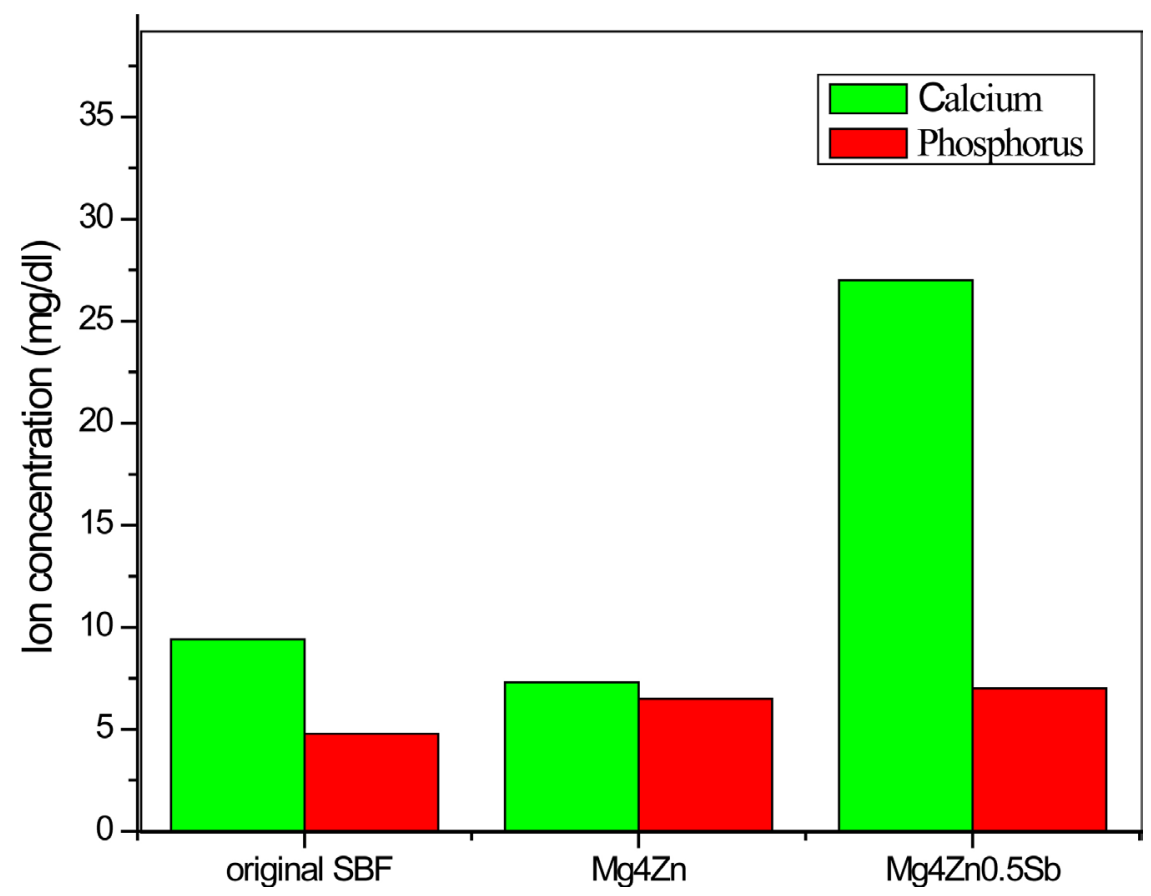

Figure 9. Concentrations of $\mathrm{Ca}$ and $\mathrm{P}$ ions in SBF after immersion of coated alloy samples for 14 days.

$\mathrm{Zn}$ alloy, is consumed to form $\mathrm{Mg}_{3} \mathrm{Sb}_{2}$ particles [8]. The refining effect of $\mathrm{Sb}$ in cast magnesium alloys has attracted some attention [26] [27] [28]. It has been reported that small additions of $\mathrm{Sb}$ had a great effect on the microstructural refinement and mechanical properties of the cast Mg-5\%Sn alloy. Adding Sb to ZA84 [27] and AZ91 [26] has also resulted in microstructural refinement and improved room and high-temperature mechanical properties. Based on the SEM observations (Figure $4(\mathrm{~d})$, Figure $4(\mathrm{~g})$ ), where no $\mathrm{Mg}_{3} \mathrm{Sb}_{2}$ compound is detected inside the $\mathrm{Mg}$ grains and all particles are found to be formed inside the interdendritic spaces. Therefore, the segregation of $\mathrm{Mg}_{3} \mathrm{Sb}_{2}$ particles at the liquid/ solid interface would restrict the growth of $\alpha$-Mg dendrites during solidification and thus refine the structure. These results are also confirmed by the previous work reported by R. Alizadeh et al. [8]. Also the addition of $0.5 \mathrm{wt} \% \mathrm{Sb}$ could improve the mechanical properties of $\mathrm{Mg}-4 \mathrm{wt} \% \mathrm{Zn}$ alloy. Owing to the relation of mechanical properties with the microstructure of the investigated alloys, the improved mechanical properties of the Sb-added alloy outcome from their microstructures. It is well known that the fine microstructure is usually beneficial to tensile properties of engineering alloys. According to Griffith's theory [29], the fracture stress of a material increases with decreasing grain size, in inverse proportion to the square root of the grain size. As shown before, the addition of $\mathrm{Sb}$ into the base $\mathrm{Mg}-4 \mathrm{wt} \% \mathrm{Zn}$ alloy cause grain refinement. Therefore, that leads to improve mechanical properties of the as-cast $\mathrm{Sb}$-added alloys which is biocompatible with mechanical properties of cortical bone [30] in comparison with the base alloy and pure Mg [24]. It's clear that the addition of Sb leads to delay the loss of the mechanical properties of the binary $\mathrm{Mg}-4 \mathrm{wt} \% \mathrm{Zn}$ alloy during 
implantation

For a closer explanation, in the early stage of an immersion, $\mathrm{Mg}$ matrix of bare samples dissolved and transformed into the stable $\mathrm{Mg}^{2+}$ ion (Equations ((2), (3))). This dissolution of $\mathrm{Mg}$ is associated with release $\mathrm{H}_{2}$ bubbles observed after immersion and $\mathrm{OH}^{-}$ions which lead to the increase $\mathrm{pH}$ of SBF [31]. After that, a protective layer of $\mathrm{Mg}(\mathrm{OH})_{2}$ is formed (Equation (4)) and prevent solution from direct contact with the substrate. This leads to reduce the degradation rate for a while. However, the aggressive $\mathrm{Cl}^{-}$ions in the medium attack the thin film of $\mathrm{Mg}(\mathrm{OH})_{2}$ and convert it into a more soluble $\mathrm{MgCl}_{2}$ (Equation (5)). So the substrate of the bare samples becomes in contact with the solution again [32].

$$
\begin{gathered}
\mathrm{Mg} \rightarrow \mathrm{Mg}^{2+}+2 \mathrm{e}^{-} \\
2 \mathrm{H}_{2} \mathrm{O}+2 \mathrm{e}^{-} \rightarrow \mathrm{H}_{2}+2 \mathrm{OH}^{-} \\
\mathrm{Mg}^{2+}+2 \mathrm{OH}^{-} \rightarrow \mathrm{Mg}(\mathrm{OH})_{2} \\
\mathrm{Mg}(\mathrm{OH})_{2}+2 \mathrm{Cl}^{-} \rightarrow \mathrm{MgCl}_{2}+2 \mathrm{OH}^{-}
\end{gathered}
$$

Equations (2)-(5) [24]

The coated $\mathrm{Mg}-4 \mathrm{Zn}$ sample which has a dense protective layer of $\mathrm{Mg}(\mathrm{OH})_{2}$ This layer protects the sample from degradation at first, but after that the $\mathrm{Cl}^{-}$ ions dissolve it into $\mathrm{MgCl}_{2}$ according to (Equation (5)). In case of coated $\mathrm{Mg}$ $4 \mathrm{Zn}-0.5 \mathrm{Sb}$, the brushite (DCPD) layer is unstable and soluble in SBF especially with increasing $\mathrm{pH}$ value. Also brushite convert into HA [33] [34] and form layer against corrosion (Equation (6)).

$$
10 \mathrm{CaHPO}_{4} \cdot 2 \mathrm{H}_{2} \mathrm{O}+12 \mathrm{OH}^{-} \rightarrow \mathrm{Ca}_{10}\left(\mathrm{PO}_{4}\right)_{6}(\mathrm{OH})_{2}+4 \mathrm{PO}_{4}{ }^{3-}+30 \mathrm{H}_{2} \mathrm{O}
$$

As shown in Figure 9 the increase of $\mathrm{Ca}$ and $\mathrm{P}$ ion concentrations after immersion is due to partially dissolve of the coated layer within the corrosion. Fortunately the presence of the $\mathrm{Ca}$ and $\mathrm{P}$ ion, and also the increasing of $\mathrm{pH}$ during immersion can encourage HA nucleation. So finally it remarks that the formation of the hydroxyapatite in the SBF is self-generated after a certain period of immersion. The formation of HA not only decrease the degradation rate, but it is also reported that during implantation, the living bone will bond through this apatite layer formed on the surface of implant so the coating step is very helpful.

\section{Conclusions}

In this article, the as-cast $\mathrm{Mg}-4 \mathrm{wt} \% \mathrm{Zn}$ and $\mathrm{Mg}-4 \mathrm{wt} \% \mathrm{Zn}-0.5 \mathrm{wt} \% \mathrm{Sb}$ alloys were investigated as degradable metallic implants. The alloys are mainly composed of the matrix $\alpha-\mathrm{Mg}$ and $\mathrm{MgZn}$ as secondary phase. The addition of Sb refines the grain size and improves mechanical properties due to the formation of the secondary phase of $\mathrm{Mg}_{3} \mathrm{Sb}_{2}$.

Immersion result showed that the $\mathrm{Ca}-\mathrm{P}$ treatment provides a protective layer that improves the corrosion resistance. The degradation rate measured at the end of immersion time improved from $3.5 \mathrm{~mm} / \mathrm{yr}, 2.5 \mathrm{~mm} / \mathrm{yr}$ for bare and coated $\mathrm{Mg}-4 \mathrm{Zn}$ respectively to $1.4 \mathrm{~mm} / \mathrm{yr}, 0.7 \mathrm{~mm} / \mathrm{yr}$ for bare and coated Sb-added alloy 
respectively. So it is clear that the addition of $\mathrm{Sb}$ and coating procedure are very effective steps to enhance degradation behavior.

\section{References}

[1] Gu, X., Zheng, Y., Cheng, Y., Zhong, S. and Xi, T. (2009) In vitro Corrosion and Biocompatibility of Binary Magnesium Alloys. Biomaterials, 30, 484-498.

https://doi.org/10.1016/j.biomaterials.2008.10.021

[2] Witte, F., Kaese, V., Haferkamp, H., Switzer, E., Meyer-Lindenberg, A., Wirth, C. and Windhagen, H. (2005) In vivo Corrosion of Four Magnesium Alloys and the Associated Bone Response. Biomaterials, 26, 3557-3563. https://doi.org/10.1016/j.biomaterials.2004.09.049

[3] Song, G. (2007) Control of Biodegradation of Biocompatable Magnesium Alloys. Corrosion Science, 49, 1696-1701. https://doi.org/10.1016/j.corsci.2007.01.001

[4] Salleh, E.M., Ramakrishnan, S. and Hussain, Z. (2016) Synthesis of Biodegradable Mg-Zn Alloy by Mechanical Alloying: Effect of Milling Time. Procedia Chemistry, 19, 525-530. https://doi.org/10.1016/j.proche.2016.03.048

[5] Zhou, P. and Gong, H. (2012) Phase Stability, Mechanical Property, and Electronic Structure of an Mg-Ca System. Journal of the Mechanical Behavior of Biomedical Materials, 8, 154-164. https://doi.org/10.1016/j.jmbbm.2011.12.001

[6] Huan, Z., Leeflang, M., Zhou, J., Fratila-Apachitei, L. and Duszczyk, J. (2010) In vitro Degradation Behavior and Cytocompatibility of $\mathrm{Mg}-\mathrm{Zn}-\mathrm{Zr}$ Alloys. Journal of Materials Science: Materials in Medicine, 21, 2623-2635. https://doi.org/10.1007/s10856-010-4111-8

[7] Boehlert, C. and Knittel, K. (2006) The Microstructure, Tensile Properties, and Creep Behavior of Mg-Zn Alloys Containing 0-4.4 wt\% Zn. Materials Science and Engineering A, 417, 315-321. https://doi.org/10.1016/j.msea.2005.11.006

[8] Alizadeh, R. and Mahmudi, R. (2010) Effect of Sb Additions on the Microstructural Stability and Mechanical Properties of Cast Mg-4Zn Alloy. Materials Science and Engineering A, 527, 5312-5317. https://doi.org/10.1016/j.msea.2010.05.029

[9] Song, Y., Zhang, S., Li, J., Zhao, C. and Zhang, X. (2010) Electrodeposition of Ca-P Coatings on Biodegradable Mg Alloy: in vitro Biomineralization Behavior. ActaBiomaterialia, 6, 1736-1742. https://doi.org/10.1016/j.actbio.2009.12.020

[10] Niu, J., Yuan, G., Liao, Y., Mao, L., Zhang, J., Wang, Y., et al. (2013) Enhanced Biocorrosion Resistance and Biocompatibility of Degradable Mg-Nd-Zn-Zr Alloy by Brushite Coating. Materials Science and Engineering C, 33, 4833-4841. https://doi.org/10.1016/j.msec.2013.08.008

[11] Shadanbaz, S. and Dias, G.J. (2012) Calcium Phosphate Coatings on Magnesium Alloys for Biomedical Applications: A Review. Acta Biomaterialia, 8, 20-30.

[12] Chen, Y., Mak, A.F., Li, J., Wang, M. and Shum, A.W. (2005) Formation of Apatite on Poly ( $\alpha$-Hydroxy Acid) in an Accelerated Biomimetic Process. Journal of Biomedical Materials Research Part B: Applied Biomaterials, 73, 68-76. https://doi.org/10.1002/jbm.b.30178

[13] Gray-Munro, J.E., Seguin, C. and Strong, M. (2009) Influence of Surface Modification on the in Vitro Corrosion Rate of Magnesium Alloy AZ31. Journal of Biomedical Materials Research Part A, 91, 221-230. https://doi.org/10.1002/jbm.a.32205

[14] Phani, A., Gammel, F. and Hack, T. (2006) Structural, Mechanical and Corrosion Resistance Properties of $\mathrm{Al}_{2} \mathrm{O}_{3}-\mathrm{CeO}_{2}$ Nanocomposites in Silica Matrix on Mg Alloys by a Sol-Gel Dip Coating Technique. Surface and Coatings Technology, 201, 
3299-3306.

[15] Mohammed, H.I., Carradò, A. and Abdel-Fattah, W.I. (2015) Noble Metals Role in Autocatalytic Phosphate Coatings on TAV Alloys. I. Ag Functionalization of Autocatalytic Phosphate Deposition on TAV Alloys. Surface and Coatings Technology, 282, 171-179.

[16] Le, V.Q., Pourroy, G., Cochis, A., Rimondini, L., Abdel-Fattah, W.I., Mohammed, H.I., et al. (2014) Alternative Technique for Calcium Phosphate Coating on Titanium Alloy Implants. Biomatter, 4, e28534. https://doi.org/10.4161/biom.28534

[17] Mohammed, H.I., Abdel-Fattah, W.I., Sallam, M.A., El-Sayed, M.E., Talaat, M.S., Faerber, J., et al. (2012) Calcium Phosphate Coating on Ti6Al4V by Autocatalytic Route. Bioinspired, Biomimetic and Nanobiomaterials, 1, 221-228. https://doi.org/10.1680/bbn.12.00012

[18] Moussa, M.E., Waly, M.A. and El-Sheikh, A.M. (2013) Effect of High-Intensity Ultrasonic Treatment on Modification of Primary Mg2Si in the Hypereutectic Mg-Si Alloys. Journal of Alloys and Compounds, 577, 693-700.

[19] Annual Book of ASTM Standards (2006) Metals-Mechanical Testing; Elevated and Low-Temperature Tests; Metallography. ASTM International, Vol. 3, Baltimore.

[20] Kokubo, T. and Takadama, H. (2006) How Useful Is SBF in Predicting in Vivo Bone Bioactivity? Biomaterials, 27, 2907-2915.

[21] Fan, J., Qiu, X., Niu, X., Tian, Z., Sun, W., Liu, X., et al. (2013) Microstructure, Mechanical Properties, in Vitro Degradation and Cytotoxicity Evaluations of Mg-1.5 Y-1.2 Zn-0.44 Zr Alloys for Biodegradable Metallic Implants. Materials Science and Engineering: $C, 33,2345-2352$.

[22] Jia, H., Feng, X. and Yang, Y. (2015) Influence of Solution Treatment on Microstructure, Mechanical and Corrosion Properties of Mg-4Zn Alloy. Journal of Magnesium and Alloys, 3, 247-252.

[23] Razavi, M., Fathi, M. and Meratian, M. (2010) Fabrication and Characterization of Magnesium-Fluorapatite Nanocomposite for Biomedical Applications. Materials Characterization, 61, 1363-1370.

[24] Bakhsheshi-Rad, H., Idris, M., Abdul-Kadir, M., Ourdjini, A., Medraj, M., Daroonparvar, M., et al. (2014) Mechanical and Bio-Corrosion Properties of Quaternary $\mathrm{Mg}-\mathrm{Ca}-\mathrm{Mn}-\mathrm{Zn}$ Alloys Compared with Binary Mg-Ca Alloys. Materials \& Design, 53, 283-292.

[25] Liu, Z., Chen, Z., Liu, X. and Tao, J. (2006) Influence of Antimony Addition on Heat Resistance of AE41 Magnesium Alloy. Chinese Journal of Materials Research, $20,186$.

[26] Guangyin, Y., Yangshan, S. and Wenjiang, D. (2000) Effects of Sb Addition on the Microstructure and Mechanical Properties of AZ91 Magnesium Alloy. Scripta Materialia, 43, 1009-1013.

[27] Balasubramani, N., Srinivasan, A., Pillai, U.S., Raghukandan, K. and Pai, B. (2008) Effect of Antimony Addition on the Microstructure and Mechanical Properties of ZA84 Magnesium Alloy. Journal of Alloys and Compounds, 455, 168-173.

[28] Nayyeri, G. and Mahmudi, R. (2010) Effects of Sb Additions on the Microstructure and Impression Creep Behavior of a Cast Mg-5Sn Alloy. Materials Science and Engineering. $A, 527,669-678$.

[29] Cong, M., Li, Z., Liu, J. and Li, S. (2014) Effect of Sr on Microstructure, Tensile Properties and Wear Behavior of As-Cast Mg-6Zn-4Si Alloy. Materials \& Design, 53, 430-434. 
[30] Hall, E. (1970) Yield Point Phenomena in Metals and Alloys. Macmillan, London. https://doi.org/10.1007/978-1-4684-1860-6

[31] Zhen, Z., Xi, T.-F. and Zheng, Y.-F. (2013) A Review on in Vitro Corrosion Performance Test of Biodegradable Metallic Materials. Transactions of Nonferrous Metals Society of China, 23, 2283-2293.

[32] Song, G., Atrens, A., St John, D., Wu, X. and Nairn, J. (1997) The Anodic Dissolution of Magnesium in Chloride and Sulphate Solutions. Corrosion Science, 39, 1981-2004.

[33] Feng, Q., Cui, F., Wang, H., Kim, T. and Kim, J. (2000) Influence of Solution Conditions on Deposition of Calcium Phosphate on Titanium by $\mathrm{NaOH}$-Treatment. Journal of Crystal Growth, 210, 735-740.

[34] Wen, C., Guan, S., Peng, L., Ren, C., Wang, X. and Hu, Z. (2009) Characterization and Degradation Behavior of AZ31 Alloy Surface Modified by Bone-Like Hydroxyapatite for Implant Applications. Applied Surface Science, 255, 6433-6438. 